\title{
Assessment of microbiological changes in fresh uncooked İnegöl meatballs stored under two different modified atmosphere packaging conditions
}

\author{
Seran TEMELLİ, Mehmet Kurtuluş Cem ŞEN, Şahsene ANAR \\ Department of Food Hygiene and Technology, Faculty of Veterinary Medicine, Uludag University, Bursa, Turkey
}

\begin{abstract}
Summary: This study was conducted to assess the microbiological changes in fresh uncooked İnegöl meatballs stored at $4{ }^{\circ} \mathrm{C}$ under ambient (Control: $\mathrm{C}$ ), and two modified atmosphere packaging (MAP) (M1: $30 \% \mathrm{O}_{2}, 40 \% \mathrm{CO}_{2}, 30 \% \mathrm{~N}_{2}$ and $\mathrm{M} 2: 60 \% \mathrm{O}_{2}$, $30 \% \mathrm{CO}_{2}, 10 \% \mathrm{~N}_{2}$ ) conditions. $\mathrm{pH}$ measurements and microbiological analyses for total aerobic mesophilic bacteria (TAMB), Pseudomonas spp., Brochothrix thermosphacta (B. thermosphacta), Enterobacteriaceae, coliform bacteria, lactic acid bacteria (LAB), and yeast and molds were performed on days $0,2,5,7,10,12,15,20$ of storage. Packaging under ambient atmosphere resulted in an increase in the counts of all microorganisms and $\mathrm{pH}$ values. TAMB in $\mathrm{C}$ group composed of mainly Pseudomonas spp. and B. thermosphacta. There was restricted growth of Pseudomonas spp. in both MAP groups. There was no change in TAMB and B. thermosphacta counts of M1 group, in contrast to an increase in LAB counts. In M2 group, an increase in TAMB and a decrease in B. thermosphacta with no change in LAB counts was observed. Results indicate that M2 group MAP, with less growth of spoilage bacteria, was apparently more beneficial for refrigerated storage of İnegöl meatballs.
\end{abstract}

Key words: Meatball, microbial quality, modified atmosphere packaging.

\section{İki farklı modifiye atmosferde paketlenen taze pişmemiş İnegöl köftelerde mikrobiyolojik değişikliklerin belirlenmesi}

Özet: $\mathrm{Bu}$ çalışma normal atmosferde (Kontrol:K) ve iki farklı modifiye atmosferde (MAP) (M1: \%30 $\mathrm{O}_{2}, \% 40 \mathrm{CO}_{2}, \% 30 \mathrm{~N}_{2}$ ve M2: $\% 60 \mathrm{O}_{2}, \% 30 \mathrm{CO}_{2}, \% 10 \mathrm{~N}_{2}$ ) paketlenerek $4^{\circ} \mathrm{C}$ 'de saklanan taze pişmemiş İnegöl köftelerde oluşan mikrobiyolojik değişikliklerin belirlenmesi amacı ile yapıldı. Saklamanın $0,2,5,7,10,12,15,20$. günlerinde pH ölçümleri yapılan örneklerde mikrobiyolojik olarak toplam aerobik mezofilik bakteri (TAMB), Pseudomonas spp., Brochothrix thermosphacta (B. thermosphacta), Enterobacteriaceae, koliform bakteri, laktik asit bakterileri (LAB) ve maya-küf analizleri gerçekleştirildi. Normal atmosferde paketleme tüm mikroorganizma sayılarında ve $\mathrm{pH}$ değerlerinde artışa neden oldu. Kontrol grubundaki TAMB sayısını başlıca Pseudomonas spp. and B. thermosphacta oluşturdu. Her iki MAP grubunda sınırlı bir Pseudomonas spp. üremesi belirlendi. M1 grubunda TAMB ve $B$. thermosphacta sayılarında bir değişme olmazken, LAB sayısında artış belirlendi. M2 grubunda TAMB sayısında artış ve $B$. thermosphacta sayısında azalma bulunurken LAB sayısında bir değişme gözlenmedi. Sonuçlar M2 grup MAP'nin, daha az sayıda bozuşma yapan bakteri üremesi nedeniyle İnegöl köftelerin soğukta saklanmasında daha yararlı olduğunu gösterdi.

Anahtar sözcükler: Köfte, mikrobiyal kalite, modifiye atmosfer paketleme

\section{Introduction}

İnegöl meatball is a traditional meat product, originating from İnegöl town in Bursa/Turkey, with the most distinctive features as: production from only a mixture of meats from lambs and veal, no addition of spice or bread crumbs, elastic texture, and grilling over charcoal fire. This type of meatballs is currently being produced in many parts of Turkey with minor modifications in its process, such as addition of fresh kashar cheese to meatball batter (1).

Today, İnegöl meatball processing is still based on traditional mentor systems in local small-medium sized enterprises. However, with the growing consumer demand to this type of meatballs in our country, several stages in its production technology, such as kneading, filling and forming, have been automated for standard industrial scale production. Under ambient atmospheric conditions, the storage life of fresh uncooked meatballs produced hygienically is indicated as long as $48 \mathrm{~h}$ at $4{ }^{\circ} \mathrm{C}$ (22). Non-hygienic processing prior/during and post processing, including primary and secondary contaminations can shorten the storage life of this product. Also, the high perishability of these meatballs due to the abundantly available nutrients and water content, which supports growth of many spoilage bacteria, is a disadvantage for the producer, retailer and consumer (11). Therefore, 
additional preventive approaches are required both to extend the short storage life and to maintain the natural quality of fresh uncooked İnegöl meatballs at refrigeration temperatures.

Meat and meat products stored under aerobic, chill conditions are generally exposed to spoilage by aerobic psychrophilic/psychrotrophic bacteria, mainly Pseudomonas spp (7). Modified atmosphere packaging (MAP), usually with mixtures of carbon dioxide $\left(\mathrm{CO}_{2}\right)$, oxygen $\left(\mathrm{O}_{2}\right)$ and nitrogen $\left(\mathrm{N}_{2}\right)$, is used to extend the storage life of these types of products $(11,18)$. The initial modification of the gas composition in MAP changes dynamically depending on respiration rate of the product and film permeability or storage structure surrounding the meat product. Elevated $\mathrm{CO}_{2}$ in MAP suppresses aerobic microbial growth, leading to a shift in the dominant microflora to bacterial groups with less spoilage potential, such as lactic acid bacteria (LAB) and/or Brochothrix thermosphacta (B. thermosphacta) (7). These bacteria have relatively slower growth rate and a different metabolic activity than pseudomonads, which could relate to meat shelf life extension (11).

Currently, there are only a few studies on determining microbiological quality and presence of pathogens in İnegöl meatballs $(3,16)$. Also, up to our knowledge, there is no information related to the microbiological evaluation of this particular product under MAP preservation. Thus, this groundwork study aims to assess the microbiological changes in fresh uncooked İnegöl meatballs stored under two different MAP conditions at $4^{\circ} \mathrm{C}$.

\section{Materials and Methods}

Preparation, packaging and sampling of the meatballs: İnegöl meatballs, which were produced (as indicated in Figure 1) by a local manufacturer, were taken aseptically after the stage of forming, and were transferred to the laboratory in cold chain within $1 \mathrm{~h}$ of production. Meatballs were separated as 3 batches, each comprised of 8 inidividual packages of $500 \mathrm{~g}$ per group, for the control ( $\mathrm{C}$ : ambient atmospheric conditions), MAP1 (M1: $30 \% \mathrm{O}_{2}, 40 \% \mathrm{CO}_{2}, 30 \% \mathrm{~N}_{2}$ ) and MAP2 (M2: $60 \% \mathrm{O}_{2}, 30 \% \mathrm{CO}_{2}, 10 \% \mathrm{~N}_{2}$ ) treatment groups. Meatballs in the $\mathrm{C}$ group were placed into polypropylene (PP) trays and were over-wrapped with polyethylene (PE) stretch film. M1 and M2 group meatballs were placed into PP containers and the packaging was carried out with BOPP film (Polinas, 124HF, $35 \mu \mathrm{m}$, New Jersey, USA) with an $\mathrm{O}_{2}$ transmission rate of 1400 $\mathrm{cm}^{3} / \mathrm{m}^{2} / 24 \mathrm{~h}$ at $23^{\circ} \mathrm{C}$ and $0 \% \mathrm{RH}$ and water vapor transmission rate of $3.5 \mathrm{~g} / \mathrm{m}^{2} / 24 \mathrm{~h}$ at $38^{\circ} \mathrm{C}$ and $90 \% \mathrm{RH}$. Packaging was performed by Reetray 25TC (Reepack, Italy). $\mathrm{pH}$ measurements and microbiological analyses of all groups, which were stored at $4^{\circ} \mathrm{C}$ for up to $20 \mathrm{~d}$, were performed on designated sampling days of $0,2,5,7,10$, $12,15,20$.

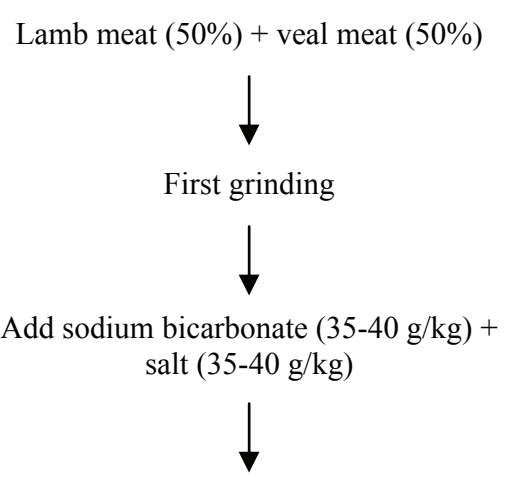

Hold mix at $2^{\circ} \mathrm{C}$ for $24 \mathrm{~h}$

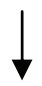

Second grinding

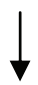

Add shredded onion

$(100-120 \mathrm{~g} / \mathrm{kg})$

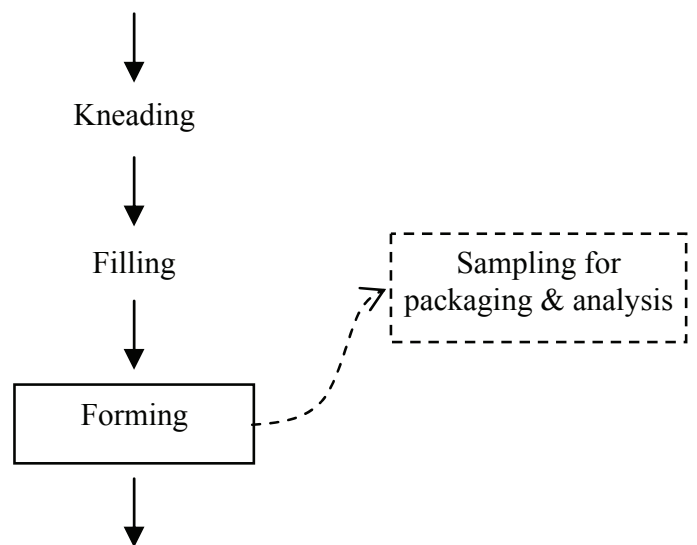

Storage at $4^{\circ} \mathrm{C}$ for $48 \mathrm{~h}$

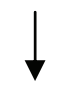

Grilling at 72 to $74^{\circ} \mathrm{C}$ for $5 \mathrm{~min}$

(central temperature)

Figure 1. Flow diagram of inegöl meatball production Şekil 1. İnegöl köfte üretim akış şeması

Determination of $\mathrm{pH}$ : The $\mathrm{pH}$ value was measured immersing the pHmeter electrode into the sample (Orion research, Model 301).

Microbiological sampling and analyses: At each sampling day, a $500 \mathrm{~g}$ package from each group was taken and $25 \mathrm{~g}$ of sample was aseptically weighed into a sterile stomacher bag (Seward, London, UK), suspended in $225 \mathrm{ml}$ sterile $0.1 \%(\mathrm{w} / \mathrm{v})$ peptone water (OXOID, CM0009), and was homogenized in stomacher (Laboratory Blender, Seward, London, UK) (21) for 2 min at normal speed at room temperature. Tenfold serial dilutions of this initial dilution was performed, plated as duplicate onto/into appropriate agar plates and incubated as follows: Total aerobic mesophilic bacteria (TAMB) on 
Table 1. Microbiological analysis and $\mathrm{pH}$ results of fresh uncooked İnegöl meatballs stored under ambient atmosphere and two different MAP conditions at $4^{\circ} \mathrm{C}$

Tablo 1. Normal ve iki farklı modifiye atmosferle paketlenerek $4^{\circ} \mathrm{C}$ 'de muhafaza edilen taze pişmemiş İnegöl köftelere ait mikrobiyolojik analiz ve $\mathrm{pH}$ sonuçları

\begin{tabular}{|c|c|c|c|c|c|c|c|c|c|}
\hline \multirow[b]{2}{*}{ Group } & \multirow[b]{2}{*}{ Day } & \multirow[b]{2}{*}{$\mathrm{pH}$} & \multicolumn{7}{|c|}{ Mean $\log \mathrm{cfu} / \mathrm{g}$} \\
\hline & & & TAMB & $\begin{array}{l}\text { Pseudomonas } \\
\text { spp. }\end{array}$ & $\begin{array}{c}B . \\
\text { thermosphacta }\end{array}$ & Enterobacteriaceae & $\begin{array}{c}\text { Coliform } \\
\text { bacteria }\end{array}$ & LAB & Yeast \& mold \\
\hline \multirow{8}{*}{$\mathrm{C}$} & 0 & 6.85 & 5.60 & 5.25 & 6.38 & 4.00 & 3.11 & 4.00 & 5.34 \\
\hline & 2 & 6.91 & 5.95 & 5.46 & 6.43 & 4.32 & 3.45 & 4.32 & 5.55 \\
\hline & 5 & 7.65 & 6.68 & 6.86 & 6.79 & 4.60 & 4.47 & 4.75 & 6.25 \\
\hline & 7 & 7.77 & 5.47 & 6.39 & 6.92 & 4.00 & 4.49 & 4.77 & 6.27 \\
\hline & 10 & 8.03 & 6.20 & 7.47 & 7.51 & 4.64 & 4.50 & 4.84 & 6.34 \\
\hline & 12 & 8.31 & 6.77 & 7.50 & 7.59 & 4.69 & 4.55 & 5.11 & 6.36 \\
\hline & 15 & 8.57 & 7.23 & 7.65 & 7.62 & 5.60 & 5.57 & 5.25 & 6.38 \\
\hline & 20 & 8.74 & 7.36 & 7.68 & 7.65 & 5.07 & 5.59 & 5.60 & 6.61 \\
\hline \multirow{8}{*}{ M1 } & 0 & 6.85 & 5.60 & 5.25 & 6.38 & 4.00 & 3.11 & 4.00 & 5.34 \\
\hline & 2 & 6.64 & 5.21 & 5.29 & 6.43 & 4.02 & 3.32 & 4.65 & 5.41 \\
\hline & 5 & 6.56 & 5.90 & 5.32 & 6.14 & 4.00 & 3.30 & 4.47 & 5.47 \\
\hline & 7 & 6.39 & 5.04 & 5.36 & 6.30 & 3.60 & 3.30 & 4.47 & 5.60 \\
\hline & 10 & 6.29 & 5.00 & 5.95 & 6.32 & 3.47 & 3.30 & 5.27 & 5.60 \\
\hline & 12 & 6.24 & 5.47 & 6.07 & 6.27 & 3.30 & 3.30 & 4.50 & 5.69 \\
\hline & 15 & 6.22 & 5.66 & 5.30 & 6.30 & 3.00 & 3.47 & 4.47 & 5.00 \\
\hline & 20 & 6.18 & 5.69 & 5.34 & 6.38 & 3.00 & 3.30 & 5.04 & 5.00 \\
\hline \multirow{8}{*}{ M2 } & 0 & 6.85 & 5.60 & 5.25 & 6.38 & 4.00 & 3.11 & 4.00 & 5.34 \\
\hline & 2 & 6.71 & 5.77 & 5.60 & 6.25 & 4.08 & 3.24 & 4.40 & 5.37 \\
\hline & 5 & 6.58 & 6.17 & 5.60 & 6.34 & 4.30 & 4.00 & 4.90 & 5.69 \\
\hline & 7 & 6.45 & 6.07 & 5.77 & 6.07 & 3.69 & 3.30 & 4.23 & 5.77 \\
\hline & 10 & 6.33 & 5.47 & 5.78 & 6.47 & 3.47 & 3.47 & 5.00 & 5.84 \\
\hline & 12 & 6.31 & 6.62 & 5.86 & 5.43 & 3.00 & 3.47 & 4.47 & 5.37 \\
\hline & 15 & 6.31 & 5.90 & 5.00 & 6.51 & 3.00 & 3.47 & 4.60 & 5.30 \\
\hline & 20 & 6.29 & 6.77 & 5.00 & 5.34 & 3.47 & 3.69 & 4.60 & 5.00 \\
\hline
\end{tabular}

Plate Count Agar Base (PCA, OXOID CM0325), incubated at $37^{\circ} \mathrm{C}$ for $24 \mathrm{~h}$; Pseudomonas spp. on Pseudomonas Agar Base (OXOID, CM0559) supplemented with Pseudomonas CFC Selective Agar Supplement (OXOID, SR0103) incubated at $25^{\circ} \mathrm{C}$ for $48 \mathrm{~h} ; B$. thermosphacta on Streptomycine Thallous Acetate Agar Base (STAA, OXOID, CM0881) supplemented with STAA Selective Supplement (OXOID, SR0151) incubated at $25^{\circ} \mathrm{C}$ for $48 \mathrm{~h}$; Enterobacteriaceae in Violet Red Bile Glucose Agar (VRBGA, OXOID CM0485) and coliform bacteria in Violet Red Bile (Lactose) Agar (VRBA, OXOID CM0107) both incubated at $37^{\circ} \mathrm{C}$ for $24 \mathrm{~h}$; LAB on De Man, Rogosa and Sharpe Agar (MRS, OXOID, $\mathrm{CM} 0361$ ) incubated at $30^{\circ} \mathrm{C}$ for $72 \mathrm{~h}$ under anaerobic conditions (Gas Generating Kit, OXOID, BR0038); yeast and mold on Rose Bengal Chloramphenicol Agar Base (OXOID, CM0549) supplemented with Chloramphenicol Supplement (OXOID SR0078) incubated at $25^{\circ} \mathrm{C}$ for $5 \mathrm{~d}$ $(6,8,17)$. After incubations, colony counts on plates were converted to $\log \mathrm{cfu} / \mathrm{g}$.

\section{Results}

Microbiological analysis and $\mathrm{pH}$ results of fresh uncooked İnegöl meatballs, which were stored under ambient atmosphere and two different MAP conditions at $4^{\circ} \mathrm{C}$ are presented in Table 1 .

The M1 and M2 group meatball samples' initial $\mathrm{pH}$ values of 6.85 decreased to 6.18 and 6.29 , respectively during storage, whereas in $\mathrm{C}$ group samples, this value inclined to 7.00 by day 5 , and reached 8.74 at the end of the storage period.

The $5.60 \mathrm{log} \mathrm{cfu} / \mathrm{g}$ initial TAMB of all groups, were determined as 7.36, 5.69, $6.77 \mathrm{log} \mathrm{cfu} / \mathrm{g}$ in the $\mathrm{C}, \mathrm{M} 1$ and M2 groups, respectively at the end of the storage period. The TAMB increase was observed only in the $\mathrm{C}$ group as ca. 2 logs, and $1 \log$ in the M2 group, whereas there was no particular change in this count in the M1 group.

For Pseudomonas spp. counts, there was a consistent increase from 5.25 to $7.68 \mathrm{log} \mathrm{cfu} / \mathrm{g}$ only in the $\mathrm{C}$ group samples during the storage period, whereas the initial counts stayed almost constant in M1 and M2 
groups. The only samples, which were characterized by approximately $1 \log$ decrease in $B$. thermosphacta counts, were from group M2. However, these counts remained stable in group M1 samples, and showed a regular increase until day 20 in the samples of $C$ group.

Initial Enterobacteriaceae counts of $4.00 \mathrm{log} \mathrm{cfu} / \mathrm{g}$ in the $\mathrm{C}$ group constantly increased during the storage period, and reached up to a final count of $5.07 \mathrm{log} \mathrm{cfu} / \mathrm{g}$. Contrary to this, in both of the MAP groups, a slight decline in the counts was observed by day 7 of the storage, where they remained around $3.00 \mathrm{log} \mathrm{cfu} / \mathrm{g}$ in the days followed. Counts of coliform bacteria in the $\mathrm{C}$ group markedly increased up to $5.57 \mathrm{log} \mathrm{cfu} / \mathrm{g}$ until the day 15 of storage, showing an overall difference of almost $2.5 \log$ from the initial count. There was a $0.5 \log$ increase in coliform bacteria in group M2 compared to M1, where counts remained almost the same during storage. LAB counts of samples from group M1 and M2 were around $4 \operatorname{logs}$ by day 7 , which then increased to 5 logs at day 10. After this day, M2 LAB counts remained around 4 logs, whereas M1 LAB counts increased up to 5 $\operatorname{logs}$ in the final day sample.

In the yeast and mold counts of both M1 and M2 group samples, a slight increase was observed during the first 10 days of storage. After this day, these numbers tended to decline down to $5.00 \mathrm{log} \mathrm{cfu} / \mathrm{g}$ until the end of the storage period. Contrary to this, the initial count of $5.34 \mathrm{log} \mathrm{cfu} / \mathrm{g}$ in the C group samples reached to a final $6.61 \mathrm{log} \mathrm{cfu} / \mathrm{g}$ by day 20 , indicating a constant increase during storage.

\section{Discussion and Conclusion}

Results from the microbiological and $\mathrm{pH}$ value analyses indicate that different atmospheric conditions could have specific effects on the growth of microorganisms residing in İnegöl meatballs during storage at $4^{\circ} \mathrm{C}$.

The initial counts for all microorganisms in this study were relatively high when compared to the initial counts indicated in other studies, which used red meat cuts $(9,18)$. However, in studies with ground meat $(8$, $17)$ and meatballs $(6,14)$, it is normal to expect relatively higher initial counts, since increase in surface area of the meat could ease access of the residing flora to nutrients and its rapid growth. Also, the initial microbial load of the ingredients (14), various preprocessing factors in hygiene applications, and specific processing steps, as two holdings at $4^{\circ} \mathrm{C}$ required during production of ready to serve İnegöl meatballs, namely: a first $24 \mathrm{~h}$ holding of the ground and salt/sodium bicarbonate added meat mixture, and a second $24 \mathrm{~h}$ holding of the formed meatball before retail service, may well affect the microbial loads. Also, for our study, the addition of sodium bicarbonate to the ground meat during process had a substantial effect on the intial $\mathrm{pH}$ of the product.
Packaging under ambient atmosphere resulted in an increase in the counts of all microorganisms and $\mathrm{pH}$ values. This type of an effect had previously been reported on red meats previously $(2,9,18)$ and on ground beef $(8,17)$. The samples from the $C$ group had relatively high increases in their specific counts of Pseudomonas spp. and coliform bacteria than the other microorganisms examined. The dominant flora mainly composed of Pseudomonas spp. followed by $B$. thermosphacta being the dominant bacteria, parallel to the results of Barrera et al. (2) and Insausti et al. (9). As indicated in literature, Pseudomonas spp. are important competitors due to their fast growth at low temperatures $\left(0-15^{\circ} \mathrm{C}\right)$, at neutral $\mathrm{pH}$ and high water activity (6) under aerobic conditions, similar to the milieu of İnegöl meatballs. Furthermore, the capability of $B$. thermosphacta to grow in aerobic/anaerobic conditions makes it an important and undesirable spoilage-related bacterium in fresh meat products (15). The increase in B. thermosphacta counts in the $\mathrm{C}$ group in this study during storage at ambient atmosphere once more indicates its presence as the second dominat bacterium in the natural flora of the meat used in the process.

When MAP group results were compared to the $\mathrm{C}$ group, a distinct restricted growth in Pseudomonas spp. was noticed. This type of suppression on the growth of pseudomonads was previously linked to the inhibitory effect of $\mathrm{CO}_{2}$ levels at or above $20 \%$ used in MAP by several authors $(6,8)$. The reduction and/or stalling of $B$. thermosphacta at constant numbers during MAP conditions in our study is concordant with the findings of Tremonte et al. (19), and discordant with the results of Tsigarida et al. (20), Skandamis and Nychas (17, 18), who reported increases in the numbers of this bacterium in their studies.

There is a growing recognition of the effect of proteolytic Enterobacteriaceae in the spoilage of refrigerated meats packaged under vacuum or MAP (5), when counts reach $7 \log \mathrm{cfu} / \mathrm{g}$. In our study, both the coliform bacteria and the Enterobacteriaceae counts in ambient atmosphere conditions incresed during storage but the Enterobacteriaceae counts did not reach the spoilage level until the end of the storage. In MAP groups, Enterobacteriaceae and coliform bacteria counts tended to remain almost constant. These results, regardless of the packaging conditions, are in accordance with the findings of Barrera et al. (2), and in contrast to the findings of Insausti et al (9), Skandamis and Nychas $(17,18)$, who reported increases in these numbers during storage at ambient and MAP conditions.

In our study, there was an increase in the LAB counts of İnegöl meatballs stored under both C and MAP groups, which did not exceed the microbial spoilage limit of $7 \mathrm{log} \mathrm{cfu} / \mathrm{g}$. However, this increase was more prominent in the $\mathrm{C}$ group compared to the other two 
groups with $\mathrm{CO}_{2}$ during storage. This instance could be related to the reduction in the growh rate of the specific LABs in the meatballs in $\mathrm{CO}_{2}$ atmosphere, compared to their growth in aerobic conditions, as reported by Dhananjayan et al. (6).

Our results on yeast and mold growth in this study indicate that the growth was faster in $\mathrm{C}$ group, whereas under MAP conditions, they remained almost constant or showed the slowest growth rate. There are reports parallel to our findings in literature explaining this type of a delay (17) by the inhibitory effect of $\mathrm{CO}_{2}$ inside the package atmosphere.

When microbiological results of M1 and M2 groups were compared, similar growth trends for all microorganism groups were observed, other than TAMB, $B$. thermosphacta, and LAB. In M1 group, there was no change in TAMB and B. thermosphacta counts, whereas the $\mathrm{LAB}$ counts increased $1 \mathrm{log}$. However, the LAB counts in M2 group remained the same throughout the storage period, whereas there was a 1 log increase in TAMB and a $1 \log$ reduction in B. thermosphacta counts at the end of this storage. The finding of TAMB increase in M2 group is probably related to higher $\mathrm{O}_{2}$ concentrations in the package. This is in parallel with the former report of Insausti et al. (9), who had used the same gas combination as ours $\left(60 \% \mathrm{O}_{2}\right.$ and $\left.30 \% \mathrm{CO}_{2}\right)$. There are similar earlier findings by Gill and Badoni (8) and Nissen et al. (13), who had used 70\% $\mathrm{O}_{2}$ and $30 \%$ $\mathrm{CO}_{2}$, and by Dhananjayan et al.(6, who used $80 \% \mathrm{O}_{2}$ and $20 \% \mathrm{CO}_{2}$, as well. Contrarily, use of higher $\mathrm{O}_{2}$ concentrations, causing the above TAMB increase in the package, had been reported to inhibit $B$. thermosphacta and $\mathrm{LAB}$ by Tremonte et al. (19), who used $60 \% \mathrm{O}_{2}$, $40 \% \mathrm{CO}_{2}$ combination against a lower $\mathrm{O}_{2}$ concentration. Mano et al. (12) also indicated that microorganisms were $\mathrm{CO}_{2}$ sensitive in the presence of high $\mathrm{O}_{2}$ concentrations but, were not $\mathrm{CO}_{2}$ sensitive at low $\mathrm{O}_{2}$ concentrations. These circumstances would explain to some extent our corresponding findings of $B$. thermosphacta inhibition and LAB suppression under high $\mathrm{O}_{2}$ in $\mathrm{M} 2$ group, compared to low $\mathrm{O}_{2}$ results in $\mathrm{M} 1$ group.

The concentrations of $\mathrm{O}_{2}$ and $\mathrm{CO}_{2}$ in different MAP conditions did not particularly affect the $\mathrm{pH}$ of our product, as previously mentioned in a study by Clark and Lentz (4). Still, the $1 \log$ increase in LAB in M1 group might have caused a slightly higher $\mathrm{pH}$ drop than in M2 group, parallel to the findings of Jayas and Jeyamkondan (10).

Results of this study indicate that MAP, with less growth of spoilage bacteria, is apparently a better choice for the refrigerated storage of İnegöl meatballs than ambient atmosphere. Overall, M2 seemed to be more beneficial, due to its superiority in B. thermosphacta inhibition and LAB suppression than M1. Further studies, including physicochemical and sensory evaluations should accompany microbiology to establish the ideal MAP conditions (by analyzing different packaging materials and gas combinations) in determining the shelflife of İnegöl meatballs under cold storage are required.

\section{Acknowledgements}

This work was supported by Uludag University Scientific Research Unit Grant, Project No: 2004/67.

\section{References}

1. Anar Ş (2010): Et ve Et Ürünleri Teknolojisi. Dora Yayınevi, Bursa.

2. Barrera O, Rodríguez-Calleja JM, Santos JA, Otero A, García-López M-L (2007): Effect of different storage conditions on E. coli O157:H7 and the indigenous bacterial microflora on lamb meat. Int J Food Microbiol, 115, 244-251.

3. Bostan K (2001): Effects of cooking and cold storage on the survival of $C$. jejuni in meatballs. Arch Lebensmittelhyg, 52, 28-30.

4. Clark DS, Lentz CP (1973): Use of mixtures of carbon dioxide and oxygen for extending shelf-life of prepackaged fresh beef. Can Inst Food Sci Technol J, 6, 194196.

5. Dainty RH, Edwards RA, Hibbard CM, Ramantanis SV (1986): Bacterial sources of putrescine and cadaverine in chill stored vacuum-packaged beef. J Appl Bacteriol, 61, 117-123.

6. Dhananjayan R, Han IY, Acton JC, Dawson PL (2006): Growth depth effects of bacteria in ground turkey meat patties subjected to high carbon dioxide or high oxygen atmospheres. Poultry Sci, 85, 1821-1828.

7. Ercolini D, Russo F, Nasi A, Ferranti P, Villani F (2009): Mesophilic and psychrotrophic bacteria from meat and their spoilage potential in vitro and in beef. Appl Environ Microbiol, 75, 1990-2001.

8. Gill CO, Badoni M (2003): Effects of storage under a modified atmosphere on the microbiological and organoleptic qualities of ground beef prepared from pasteurized manufacturing beef. Int J Food Sci Tech, 38, 233-240.

9. Insausti K, Beriain MJ, Purroy A, Alberti P, Gorraiz C, Alzueta MJ (2001): Shelf life of beef from local Spanish cattle breeds stored under modifed atmosphere. Meat Sci, 57, 273-281.

10. Jayas DS, Jeyamkondan S (2002): Modified atmosphere storage of grains, meats, fruits and vegetables. Biosystems Eng, 82, 235-251.

11. Koutsoumanis KP, Stamatiou AP, Drosinos EH, Nychas G-JE (2008): Control of spoilage microorganisms in minced pork by a self-developed modified atmosphere induced by the respiratory activity of meat microflora. Food Microbiol, 25, 915-921.

12. Mano SB, Ordoñez JA, Garcia de Fernando GD (2000): Growth/survival of natural flora and Aeromonas hydrophila on refrigerated uncooked pork and turkey packaged in modified atmospheres. Food Microbiol, 17, 657-669. 
13. Nissen H, Alvseike O, Bredholt $\mathbf{S}$, Holck A, Nesbakken T (2000): Comparison between the growth of Yersinia enterocolitica, Listeria monocytogenes, Escherichia coli O157:H7 and Salmonella spp. in ground beef packed by three commercially used packaging techniques. Int J Food Microbiol, 59, 211-220.

14. Ozturk A, Yilmaz N, Gunes G (2010): Effect of different modified atmosphere packaging on microbial quality, oxidation and colour of a seasoned ground beef product (meatball). Packag Technol Sci; 23, 19-25.

15. Pin C, Garcia de Fernando GD, Ordonez JA (2002): Effect of modified atmosphere composition on the metabolism of glucose by Brochothrix thermosphacta. Appl Environ Microbiol, 68, 4441-4447.

16. Sarımehmetoğlu B, Küplülü Ö, Kaymaz Ş (1998): Hamburger ve İnegöl köftelerinden Escherichia coli O157:H7 izolasyonu. Ankara Üniv Vet Fak Derg, 45, 221227.

17. Skandamis PN, Nychas G-JE (2001): Effect of oregano essential oil on microbiological and physico-chemical attributes of minced meat stored in air and modifed atmospheres. J Appl Microbiol, 91, 1011-1022.

18. Skandamis PN, Nychas G-JE (2002): Preservation of fresh meat with active and modified atmosphere packaging conditions. Int J Food Microbiol, 79, 35-45.
19. Tremonte $P$, Sorrentino E, Succi $M$, Reale A, Maiorano G, Coppola R (2005): Shelf life of fresh sausages stored under modified atmospheres. J Food Prot, 68, 2686-2692.

20. Tsigarida E, Skandamis PN, Nychas G-JE (2000): Behaviour of Listeria monocytogenes and autochthonous flora on meat stored under aerobic, vacuum and modified atmosphere packaging conditions with or without the presence of oregano essential oil at $5^{\circ} \mathrm{C}$. J Appl Microbiol, 89, 901-909.

21. Türk Standartları Enstitüsü (1998): Et ve Et Mamülleri Numune Alma ve Analiz Numunelerinin Hazırlanmasi, Bölüm 1-Numune Alma, TS 3135. Türk Standartları Enstitüsü Ankara.

22. Türk Standartları Enstitüsü (2007): Köfte-Pişmemiş TS 10581. Türk Standartları Enstitüsü, Ankara.

Geliş tarihi: 01.07.2010 / Kabul tarihi: 17.02.2011

\author{
Address for correspondence: \\ Assoc. Prof. Dr. M. K. Cem Sen \\ Department of Food Hygiene and Technology \\ Faculty of Veterinary Medicine \\ Uludag University 16059, Görükle Campus \\ Bursa, Turkey \\ Email:mkcsen@uludag.edu.tr
}

